\title{
МЕТОДОЛОГІЧНИЙ ПІДХІД ДО ВИМІРЮВАННЯ ПРОГРЕСУ У НАПРЯМУ НАБЛИЖЕННЯ ДО МОДЕЛІ ЕКОНОМІКИ ЗАМКНЕНОГО ЦИКЛУ
}

\author{
Шевченко Тетяна Іванівна. \\ кандидат економічних наук, доцент \\ Сумський національний аграрний університет (м.Суми, Україна) \\ ORCID: 0000-0002-3213-819X \\ tanya.shevchenko@snau.edu.ua
}

У статті удосконалено методологічний підхід до вимірювання прогресу у напряму наближення до моделі економіки замкненого циклу, який грунтується на оцінці індикаторів за окремими сегментами ресурсного циклу, що є підгрунтям для розробки рамки кругових даних для підприємств усіх секторів економіки, від видобутку сировини до виготовлення кінцевих виробів, від збору відпрацьованих виробів через відновлення до виготовлення виробів із вторинних матеріалів. Запропонований підхід є внеском у розширення метричного апарату кругової економіки.

Ключові слова: кругова економіка, циркулярна економіка, економіка замкненого циклу, вимірювання прогресу, ресурсний цикл, рецикліне, вторинні ресурси, переробка відходів.

DOI: https://doi.org/10.32845/bsnau.2019.4.6

Актуальність теми дослідження та аналіз останніх піблікацій. Питання якомога тривалішого збереження цінності матеріалів та виробів в економічній системі з метою усунення небажаних виходів, з одного боку, та мінімізації втрат матеріалів, з іншого, $є$ предметом дискусій вже протягом декількох десятиліть. За цей час деякі терміни, що з'явились у науковій літературі, такі як «циркулярність» (з англ. «circularity»), «циклічність» (з англ. «сусlicity»), «циркулювання» (з англ. «circulating») та інші, стали досить популярними, особливо після прийняття Європейською комісією «Плану дій щодо кругової економіки» [18], а також деяких законодавчих документів у Німеччині [21], Китаї [39], Японії [32]. Крім цього, наразі спостерігається тенденція проникнення ідей кругової економіки в різні сфери діяльності людини, зокрема з'являються терміни: циклічно-орієнтований дизайн (з англ. «circular design»), стратегії кругової економіки (з англ. «circular strategies») [4, 36], суспільство кругової економіки (з англ. «circular society») [35, 37], бізнес-моделі кругової економіки (з англ. «circular business model») [24], виріб кругової економіки (з англ. «circular product») [14], матеріальний потік кругової економіки (з англ. "circular material flow») [29], замкнутий ланцюжок поставок (з англ. "circular supply chain») [42], споживання відповідно до кругової економіки (з англ. «circular consumption») [54], поведінка споживача для кругової економіки (з англ. "circular behaviour») [53, 43] та інші. 3'явився новий тип показників [46] для вимірювання прогресу у напряму переходу від лінійної до кругової моделі економіки.

Слід підкреслити, що повна концептуалізація моделі кругової економіки (циркулярної економіки, економіки замкнутого циклу) ще не відбулася [47]. Не дивлячись на тривалі дискусії серед науковців, поки що немає єдиної думки стосовно соціально-економіко-екологічного вимірювання циркулярності, тривають обговорення стосовно кількості ланок в ієрархії управління відходами, які покриває кругова економіка, а також відносно переліку можливих бізнес-моделей щодо створення вартості з відходів. Не зважаючи на це, питання введення в дію моделі кругової економіки (операціоналізації) потребує подальших досліджень $[38,10]$. На наш погляд, це питання лежить у площині розробки відповідних стратегії, що покликані створити передумови для транссрормації індустрії у відповідності до завдань кругової економіки.

Поступове та безперервне нарощування потенціалу у напряму багатократного обертання матеріалів та виробів у економічній системі, максимальне використання наявного потенціалу, покладаючись на пріоритети у збереженні цінності виробів/вузлів/матеріалів в цій системі якомога довше, - це ті ключові завдання, на яких має бути сффокусований план дій стратегії щодо операціоналізації моделі економіки замкнутого циклу.

Невід'ємним елементом процесу операціоналізації $є$ вимірювання прогресу щодо руху від лінійної до кругової моделі економіки. У цьому відношенні потребує обірунтування процедура переведення відповідних концептів у конструктори (систему індикаторів), з подальшим пошуком засобів фіксації характеристик об'єктів (індикаторів), обгрунтуванням цих характеристик, та подальшим розробленням підходів прямого визначення характеристик, доступних для спостереження та вимірювання. Виходячи 3 того, що «6Rs» стратегії [50], які спрямовані на замикання та уповільнення матеріальної петлі, є концептуальним підірунтям кругової економіки, об'єктом операціоналізації моделі є цінність матеріалів та виробів/їх частин. Збереження цінності конкретного матеріалу в економіці якомога довше означає забезпечення максимальної кількості його обертів, а також подовження часу кожного оберту, покладаючись на доступні технології та інновації.

Нещодавні дослідження актуалізують питання щодо розробки метрик для моніторингу прогресу в реалізації стратегій кругової економіки [34, 9]. Існуюча практика вимірювання прогресу, що базується переважно на показниках повторного використання (з англ. «reuse») та рециклінгу (з англ. «recycling»), не в повній мірі відображає базові концепти кругової економіки, зокрема такі як життєвий цикл багатократного обертання матеріалу/виробу/деталі, що вимірюється кількістю обертів, їх тривалістю. Крім того, потребують розробки науково-методичні підходи щодо вимірювання, які дозволять відповісти на питання: наскільки повно використовується наявний доступний потенціал щодо збереження цінності матеріалів та виробів за «6Rs» стратегіями конкретної території? Також важливо відстежувати прогрес у нарощуванні нового потенціалу, який ще не має форми ресурсів (явний недоступний потенціал), але в майбутньому створені можливості дозволять скоротить кількість 
небажаних виходів у системі.

Дане дослідження ірунтується на припущенні, що збереження цінності матеріалів та виробів в економіці $є$ результатом розвитку структури сукупних ресурсних циклів території у напряму замикання та уповільнення матеріальних петель. Розвиток структури ресурсних циклів відбувається за рахунок реконструкції існуючих циклів, а також формування нових. На наш погляд, сегментація ресурсного циклу могла б стати дієвим інструментом для вимірювання прогресу у наближенні до кругової економіки через дослідження структурних змін ресурсних циклів території викликаних замиканням та уповільненням матеріальних петель. У цьому дослідженні робиться спроба розробити методологічний підхід до вимірювання прогресу щодо реалізації стратегій кругової економіки. Запропонований підхід $€$ внеском у розширення метричного апарату щодо операціоналізації моделі кругової економіки.

Результати дослідження. Термін «кругова економіка» не $є$ новим і поєднує у собі принципи низки напрямків наукової думки, деякі з них беруть початок з 1960-х років. Виходячи 3 визначення терміну «кругова економіка» [40, 16, 31, 24] та змісту відповідних наукових напрямів, що ії визначають, зокрема продуктивна економіка, індустріальна екологія, дизайн «від колиски до колиски», біомімікрія та інші [50, 3, 8 , 6], основна ідея нової моделі полягає у забезпеченні багатократного обертання конкретних матеріалів/речовин та конкретних виробів/їх частин шляхом передбачення технічного аналога редуцента екосистеми для всіх «небажаних» виходів техногенної системи. Як зазначає Мюрей та ін. [38], слово «кругова» (з англ. "circular") має описове значення, що відноситься до поняття циклу. Вчені обгрунтовують це наявністю двох циклів: біогенного та техногенного. Відносно останнього можна виділити два типи техногенних циклів: (1) цикл багатократного обертання матеріалу та (2) цикл багатократного використання виробу/його частин [45]. За цією логікою, конкретний матеріал має свій власний шлях - він послідовно обертається через ряд виробів і цей ряд, у тому числі, визначає тривалість життєвого циклу цього матеріалу. Час (тривалість) знаходження матеріалу у економічній системі залежить як від кількості його обертів, так і від тривалості кожного оберту. Для збільшення кількості обертів життєвого циклу матеріалу доцільно формувати оптимальний ряд виробів [44].

На думку Грейсона [27], К. Боулдінг є автором концепції кругової економіки і це є цілком справедливим. Боулдінг першим описав модель економіки замкненого циклу [7], за якою виходи усіх процесів економічної системи пов'язані із входами інших процесів. Згодом ідея кругової економіки отримала подальший розвиток в роботі Стахеля та Редея-Мулвея [49].

Б. Коммонер підкреслює важливість існування «технічного редуцента» в економіці [13], оскільки утворення відходів $є$ неминучим для будь-якого техногенного циклу, вони тільки можуть переходити з однієї форми в іншу або переміщуватися у просторі. Коммонер описує біогенні цикли в природі та зазначає, що для будь-якої органічної речовини, що продукується екосистемою, десь у природі існує фермент, здатний розкладати цю речовину. Тому, коли людина синтезує нову органічну речовину зі структурою, що значно відрізняється від природних речовин, цілком ймовірно, що ця речовина буде накопичуватися [13]. Наприклад, полімери стійкі до процесу розкладання, про що свідчить їхня довговічність, i, як наслідок, вони накопичуються в природі, як тільки втрачають свою цінність в економічній системі.

Проблему обміну речовин між природою та економікою досліджував І. Комар [2]. Комар визначав ресурсні цикли як сукупність перетворень та просторових переміщень певної речовини або групи речовин, що виникають на всіх етапах її використання людиною, включаючи підготовку до експлуатації, вилучення 3 навколишнього середовища, обробку, споживання та повернення у довкілля. Автор підкреслює, що обмін речовин між суспільством та природою має яскраво виражений характер поліциклічного процесу, і загальний потік речовин в системі «природа - суспільство природа» можна розділити на окремі ресурсні цикли. Комар зазначає, що кожен цикл має ряд супутніх та додаткових підциклів, які розвиваються на основі диверсифікованого використання основного ресурсу. Він виділяв ресурсні цикли та підцикли відповідно до типу основної речовини (сполучення речовин).

З часом, новим імпульсом щодо концептуалізації моделі циркулярної економіки стала низка докладів фонду EllenMcArthur, які висвітлили ієрархію стратегій кругової економіки, зокрема повторне використання, ремонт, відновлення, модернізція, перепрофілювання та рециклінг. Категоріальний апарат нової моделі розвивається поступово, продовжують з'являтись нові терміни, зокрема такі як «витік» (з англ. «leakage»), «період відновлення» (з англ. «recovery horizon») та інші [14]. Бломсма та Бренан [9] інтерпретують кругову економіку як всеохоплюючу концепцію (з англ. «umbrella concept»), яка пропонує новий «запуск» існуючих 6R стратегій - перехід від одиничних стратегій до різних конфігурацій - ситуацій, коли дві або більше різних стратегій реалізуються разом послідовно або паралельно. На думку цих вчених відповідні метрики та інші методи оцінки будуть відігравати ключову роль у більш глибокому розумінні цих процесів.

За оцінками експертів фонду EllenMcArthur, ЄC-27 все ще втрачає величезну кількість матеріалів, зокрема станом на 2010 рік тільки 40\% від загального обсягу відходів було перероблено або повторно використано. За розрахунками тільки у ЄС економія матеріальних ресурсів може скласти 380 млрд. дол. при впровадженні кругових бізнес-моделей. Ці висновки зроблені експертами при оцінці потенціалу бізнесу щодо створення вартості з відходів [16].

Експерти фонду [16] виділяють чотири можливих джерела створення вартості через кругові бізнес-моделі:

1) потенціал внутрішнього кола (з англ. «power of the inner circle») - чим менше коло, тобто чим менше виріб потрібно змінювати (ремонт, модернізація чи рециклінг) і чим швидше він повертається до використання, тим вище потенційна економія матеріалу, праці, енергії та капіталу, закладеного у виріб, а також тим менший збиток від забруднення довкілля у вигляді негативних екстернальних ефректів, зокрема парникових газів, викидів, скидів та відходів;

2) потенціал тривалості оберту (з англ. «power of circling longer») - передбачає максимізацію кількості циклів та тривалості кожного циклу;

3) потенціал каскадного використання (з англ. «power of cascading use») - полягає у диверсифікації повторного використання матеріалу у ланцюжку створення вартості, наприклад, каскадний ланцюжок бавовни: «одяг - меблі- 
будівельні матеріали», після чого передбачається безпечне виведення залишків матеріалу у біосферу;

4) потенціал «чистого циклу» (з англ. "power of pure circles») - передбачає підвищення продуктивності матеріалу за рахунок використання безпечних нетоксичних матеріалів, у тому числі біорозкладальних матеріалів, зокрема біопластику та біополіетилену.

Зараз у країнах світу спостерігається тенденція розриву між удосконаленням технологій виробництва виробів та технологій переробки відходів. Розрив полягає у тому, що технології переробки розробляються для відходів утворених у минулому, а 3 розвитком технологій виробництва змінюються і характеристики відходів, пошук технологій переробки яких перекладається на майбутнє. Звідси висновок про те, що технологічні можливості щодо переробки відходів завжди будуть обмежені, якщо вони не розробляються одночасно із технологіями виробництва. Ця невідповідність може бути усунута якщо невід'ємною складовою розробки технології виробництва стане передбачення технічного редуцента для переробки усіх небажаних виходів нового процесу, що створює ця технологія. Стосовно ж накопичених відходів, по мірі розвитку технологій переробки та одночасним виснаження природних родовищ, багато накопичувачів можуть розглядатися як повноцінні родовища корисних копалин техногенного типу. Повертаючись до переліку потенційних джерел створення вартості з відходів, при забезпеченні багатократного обертання матеріалів та виробів зусиллями відтворювальної системи, залучення первинного ресурсу $є$ необхідним як для задоволення зростаючих потреб, якщо зростання має місце, так і для компенсації втрачених матеріалів. Техногенні родовища слід розглядати як джерело матеріалів для компенсації відповідних втрат та задоволення зростаючих потреб замість природних родовищ.

Таким чином, до переліку можливих джерел створення вартості можна додати ще одне джерело - «потенціал розробки техногенних родовищ». Відсутність наявних технологій переробки небажаних виходів процесів, а також пануючі стереотипи лінійної моделі призвели до утворення великої кількості техногенних родовищ у багатьох країнах світу у тому числі в Україні. Ці родовища на сьогодні можуть розглядатися як джерело створення цінності у напряму подовження призупинених у минулому ресурсних циклів. До техногенних родовищ корисних копалин слід віднести відвали, шламосховища, хвостосховища, полігони, терикони, звалища та інші різні накопичувачі. На сьогоднішній день багато техногенних родовищ характеризуються більш високим вмістом цінних компонентів ніж природні родовища. Наприклад, в Україні у відходах Запорізького титано-магнієвого комбінату вміст скандію, ванадію, танталу, хрому, титану вище, ніж в природних родовищах. Багато цінних компонентів міститься у відходах Миколаївського ртутного комбінату (літій, ртуть), Черкаського заводу хімічних реактивів (нікель) та інші. Наукові дослідження і практичний досвід свідчать про високий ресурсний потенціал відходів виробництва, що утворювалися 20 років тому. Згідно результатів досліджень [1], через недосконалість технологій видобутку в землі залишалося до 70\% нафти, 30\% вугілля, 20\% залізної руди, планові втрати кам'яного вугілля складали 40\%, нафти - 50\%. При видобутку калійних солей і слюди в відвалах залишалося 80\% сировини.
Хоча концепція кругової економіки стає все більш популярною та вважається моделлю сталого використання природних ресурсів [48], концепція «нульових відходів» не втрачає своєї актуальності. Фактично, остання є одним із приоритетних напрямів нової моделі, паралельно із переходом на поновлювані джерела енергії та усуненням шкідливих речовин [16]. На сьогоднішній день стратегія «нульових відходів» спрямована на «нульові звалища» шляхом відведення відходів від звалищ [55]. Існуючі стратегії країн-членів ЄС були розроблені відповідно до завдань ієрархії управління відходами, яка фактично $€$ їх наріжним каменем, в спробі наблизитися до цілі «нульових звалищ» [28]. В той же час, підхід «нульових звалищ» не в повній мірі корелює з 6R стратегіями кругової економіки.

Незважаючи на численні дослідження у напряму розробки метрик для кругової економіки, деякі вчені зазначають, що питання вимірювання прогресу знаходиться на ранній стадії [11]. Серед низки досліджень можна виділити дві недавні праці, а саме Сайдані та ін. у напряму розробки класифікації показників кругової економіки та Пархоменко та ін. присвяченої аналізу 63 метрик кругової економіки [46].

Відправним пунктом для будь-якої метрики є одиниця, що використовується для вимірювання циркулярності або циклічності (з англ. «circularity»). Для кількісної оцінки циклічності матеріалу та виробу існуючі метрики ґрунтуються на різних типах одиниць, таких як маса $[15,29,41]$, частота як кількість обертів [23], час як тривалість оберту [22] та кількість процесів [5]. У випадку маси як одиниці вимірювання, оцінка може ґрунтуватися на використанні натурального показника [29] або вартісного [34]. 3 точки зору вкладу у циклічне або лінійне використання матеріалу/виробу, індикатори можуть вимірювати позитивні або негативні параметри в системі. Всі методики оцінки циркулярності можуть бути засновані на одному синтетичному індикаторі або на сукупності індикаторів, які зазвичай діляться на кілька категорій [20]. Циклічність матеріалів та виробів може бути оцінена на всіх рівнях $[19,26]$, включаючи мікро-рівень - рівень окремого підприємства, мезо-рівень - рівень місто, індустріальний парк, промисловий сектор, а також макрорівень - національний або регіональний.

У своєму дослідженні Елія та ін. [20] запропонували чотирьохелементну рамку для вимірювання прогресу кругової економіки, яка складається з (1) процесів, що підлягають моніторингу, (2) відповідних дій суб'єктів, (3) вимог щодо вимірювання та (4) рівнів реалізації. Не дивлячись на те, що ця рамка охоплює всі стадії життєвого циклу виробу, вона ігнорує процеси перетворення речовини в матеріал [33], а ці процеси охоплюють значний сегмент ресурсного циклу, особливо у країнах із значною часткою підприємств добувних галузей у структурі економіки [51].

Ряд подібних методологій [30] використовується для вимірювання циркулярності економіки з подібним широким діапазоном цілей, що, ймовірно, пов'язано з тим, що деякі вчені розглядають модель кругової економіки як інструмент для операціоналізації концепції сталого розвитку.

Фонд EllenMacArthur and Granta [15] розробили комплексний індикатор, який оцінює циклічність матеріалів на рівні виробу, використовуючи в якості інструменту аналіз потоків матеріалів з акцентом на масу як одиницю виміру циклічності. Індикатор циклічності матеріалу фокусується на 
відновленні потоків матеріалу на рівні виробу. Показник циклічності матеріалу, безсумнівно, $є$ актуальним, але цей підхід може бути застосований тільки до підприємств з предметною спеціалізацією. Крім цього, було б некоректним порівнювати такі підприємства з різною номенклатурою виробів, що випускається.

Лінде та ін. запропонували показник циклічності на основі економічної вартості на рівні виробу [34]. Покладаючись на витрати в ланцюжку створення цінності, автори запропонували метрику для вимірювання циклічності, що ґрунтується на економічній оцінці частин виробу [34].

На думку Франклін-Джонсон та ін. [22], циркулярність відображає період часу, протягом якого ресурс забезпечує цінність, і цей період можна виміряти показником довговічності. Автори підкреслюють, що довговічність має відношення до ресурсу, а не до виробу. Ця ідея була пізніше розвинута Фег та ін. [23] шляхом поєднання циклічності як частоти використання ресурсу та довговічності ресурсу. Ці вчені підкреслюють, що циклічність ресурсу не обов'язково є показником його довговічності, оскільки ресурс можна використовувати багато разів, але протягом короткого проміжку часу [23]. Однак це твердження не зовсім коректне, оскільки життєвий цикл ресурсу залежить від терміну корисного використання того чи іншого виробу. На нашу думку, при оцінці циклічності нелогічно розривати матеріал та вироби, оскільки циклічність матеріалу вимірюється в межах ряду виробів, у яких послідовно використовується той чи інший матеріал.

Подібно до вищезазначених методологій, Бейлі та ін. [5] стверджують, що циклічність може бути виміряна за допомогою «довжини шляху». «Довжина шляху» може бути визначена як середнє число процесів, в яких задіяні ресурси, перш ніж вони покинуть систему в якості відходів [5]. Фег та ін. [23] робить цінний коментар до цього підходу, з яким ми цілком погоджуємося, - акцент на процес породжує свої власні обмеження - довжина шляху буде залежати від того, як обмежені межі системи і процеси.

Парк та Чертоу [41] обґрунтовують доцільність застосування інструменту доступних технологій для вимірювання потенціалу повторного використання ресурсу. Основна ідея показника потенціалу повторного використання полягає в тому, що саме знання того, де і як використовувати відходи, створює можливість повторного їх використання. Не дивлячись на те, що матеріали можуть мати залишкову цінність, деякі з них потрапляють на звалища, оскільки ми не знаємо, як їх повторно використовувати, або не можемо використовувати за відсутності технологій. I навпаки, деякі матеріали зазвичай відновлюються на основі накопичених знань, те, що визначає «можливість» повторного використання матеріалу - це рівень знань, який привів до технологічних інновацій для повторного використання. Якщо потенціал повторного використання високий, це означає, що матеріал містить більше компонентів, які можуть бути відновлені з використанням доступних технологій [41].

Узагальнюючи вищеописані методологічні підходи до вимірювання прогресу кругової економіки, варто відзначити, що все, що нам вдалося б виміряти за допомогою цих метрик, відноситься до результатів рішень прийнятих у минулому. Веліс та Брунер [52] підкреслюють, що вимірювання циклічності має відбуватися у декількох точках системи, щоб розуміти поточний технічно досяжний рівень циклічності та слабкі місця де інновації $€$ найбільш необхідними. У статті
Брунгарда та ін. [8], «потенціал циклічності» розглядається безпосередньо в контексті матеріалу. Автори стверджують, що матеріал, синтетичний або мінеральний, який має потенціал залишатися в замкнутій системі виробництва, відновлення і повторного використання (технічний метаболізм), зберігаючи свою цінність протягом багатьох життєвих циклів виробів, може бути визначений як «промислова поживна речовина». Чи стане вихід техногенного процесу поживною речовиною чи ні, це, серед іншого, залежить від економічних обставин, які з часом змінюються. Отже, потенціал циклічності конкретних матеріалів та виробів/деталей $є$ набутою властивістю, яка має динамічний характер. Для безперервного нарощування потенціалу циклічності нові метрики повинні бути спрямовані на виявлення і моніторинг всіх можливих форм прояву цього потенціалу. У цьому контексті прогрес у напряму до кругової економіки - це не тільки фрактична величина щодо збереження цінності матеріалу/виробу, але й передумови, створені для цього.

3 часом ресурсні цикли розвиваються, що означає зміну їхньої структури $[12,2]$. Відповідно до цих міркувань, в контексті кругової економіки розвиток ресурсних циклів включає не тільки зміну територіальних структур, але і їх якісну трансформацію відповідно до трьох критеріїв:

- усунення токсичних та шкідливих речовин/матеріалів у виробництві;

- максимальна заміна невідновлюваних ресурсів відновлюваними;

- зменшення відходів до нуля.

Що стосується першого орієнтиру, заміна токсичних матеріалів нетоксичними може привести до утворення абсолютно нових ресурсних циклів або реконструкції існуючих через зміну способу трансформації основної речовини або сполучення речовин на певній стадії. Щодо наступних двох орієнтирів: якщо неможливо замінити невідновлюваний ресурс відновлюваним, необхідно розвивати ресурсний цикл у напрямку відновлюваності матеріалу в межах техногенної системи і зосередити увагу на окремому сегменті ресурсного циклу. У разі забезпечення відновлюваність матеріалу зусиллями техногенної системи, залучення первинного матеріалу буде необхідним тільки для задоволення зростаючих потреб та/або покриття неминучих втрат.

Ресурсний цикл можна поділити на два основних сегменти:

1) «перетворення мінералу у матеріал» (видобутокпереробка-збагачення)

2) «перетворення матеріалу у виріб» (виробництвовикористання-виробництво'»).

Для кругової економіки другий сегмент може бути представлений як цикл багатократного обертання матеріалу, коли конкретний матеріал використовується послідовно у певному ряді виробів. Для уповільнення потоку важливо виділяти цикл багатократного використання виробу у межах кожного витку циклу матеріалу. Дії щодо уповільнення та замикання матеріальної петлі - розвиток другого сегменту ресурсного циклу - неминуче призведе до звуження потоку першого сегменту. Отже, подовження життєвого циклу конкретного матеріалу призводить до трансформації всього ресурсного циклу. Безумовно, звуження потоку цього сегменту у тому числі $є$ наслідком дематеріалізаційних процесів, однак для оцінки необхідно враховувати обсяги звуження потоку речовини обумовлені процесами замикання та уповільнення

Вісник Сумського національного аграрного університету 
петлі.

Другий сегмент ресурсного циклу - «перетворення матеріалу у виріб» може бути представлений у вигляді спіралі (рис. 1).
Будь-який процес ресурсного циклу, у тому числі процеси відтворення цінності (рециклінг, модернізація та відновлення), має свої власні виходи: бажані та небажані. За логікою кругової економіки, для будь-якого небажаного виходу має існувати вхід - відповідний процес.

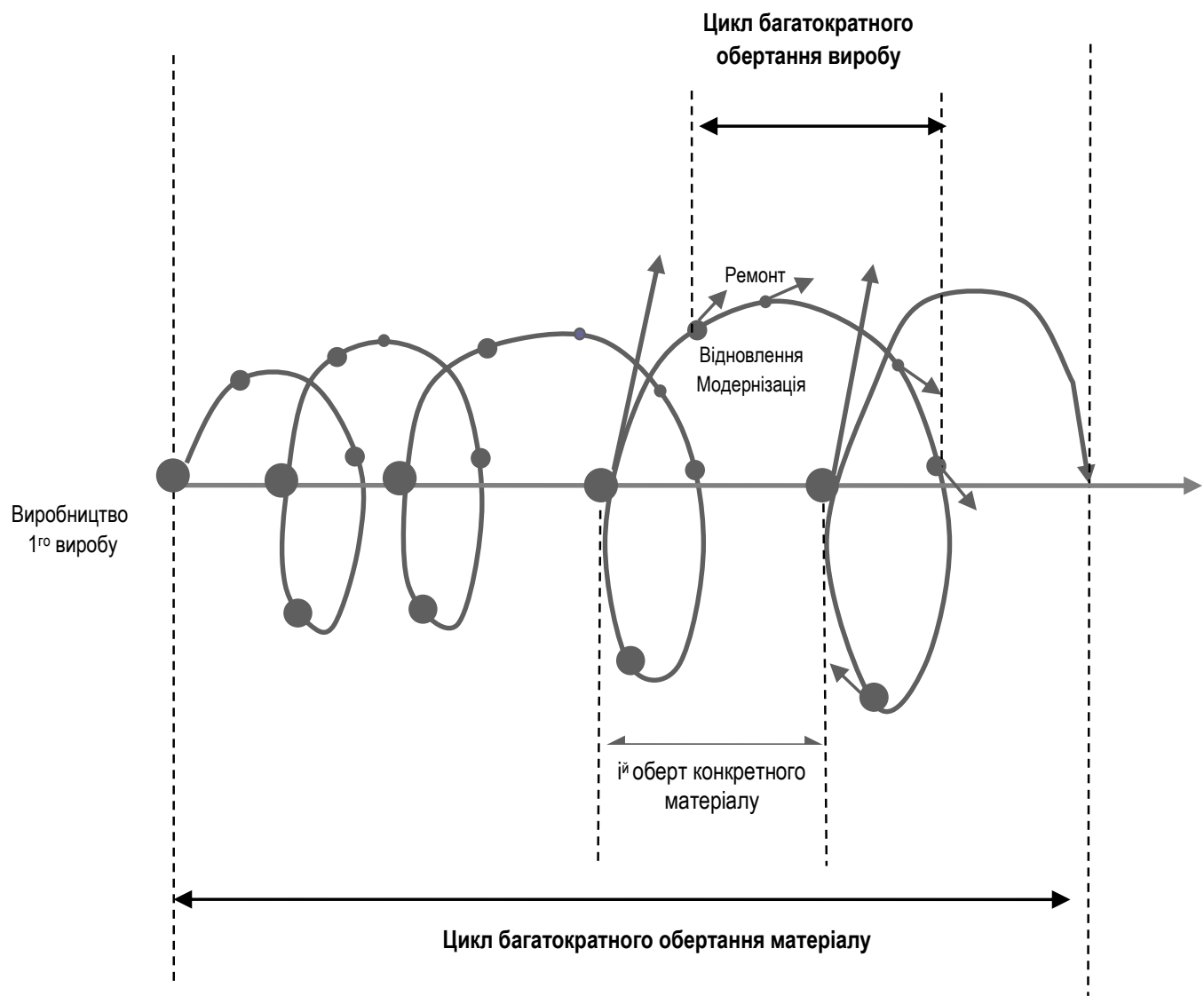

Рисунок 1 - Сегмент багатократного перетворення матеріалу у виріб

Припустимо, що на національному рівні будь-яка територія складається 3 певною кількістю ресурсних циклів. Цикл на рівні території може бути представлений не повністю, а як окремий фрагмент, тобто як певна частина всього ресурсного циклу. Також припустимо, що кожен з цих циклів складається з певною кількістю сегментів. Тоді будь-яка територія складається з окремих сегментів циклів. Сегмент певного циклу - це набір процесів, кожен з яких має свою територіальну приналежність. Процес, який відбувається в межах будь-якого сегменту, має свої входи і виходи. Як зазначено вище, виходи процесу можна поділити на дві категорії:

(1) бажаний вихід - цільовий продукт для подальшого споживання;

(2) небажаний вихід - нецільовий вихід, який потребує покриття наявними технологіями переробки або повторного використання.

У свою чергу небажані виходи можна поділити на обсяг виходу, що покривається доступними технологіями, та обсяг виходу, який потенційно може бути покритий такими технологіями у майбутньому. На думку Гладишева [25], до технологій рециклінгу можна віднести: базові технології, сателітні, автономні, гібридні та асиміляційні. Базові технології рециклінгу працюють у широкому діапазоні коливань основної сировини, ці технології здатні залучати сировину для переробки або використання ззовні. Сателітні технології рециклінгу - це додаткові технології, при яких рециклінг інтегрується в певну частину виробничого комплексу. Автономні технології створені виключно для вирішення проблеми небажаних виходів процесів без інтеграції основних технологій. Гібридні технології призначені для спільної переробки небажаних виходів процесів виробничого сегменту (відходи виробництва) та сегменту споживання (відходи споживання). Технології асиміляції забезпечують екологічно безпечне виведення небажаного потоку матеріалів з техногенних циклів в природне середовище [25].

Таким чином, циркулярність економічної системи територій певного рівня може бути оцінена на основі вимірювання рівня покриття всіх небажаних виходів процесів, які відносяться до сегментів ресурсних циклів території.

Припустимо, що всі небажані виходи процесів, що належать певній території, можуть бути покриті відповідними технологіями в майбутньому. 3 точки зору наявності різних форм прояву потенціалу циркулярності економічної системи, таких як наявні ресурси, невикористані резерви та можливості, циклічність матеріалу може бути інтерпретована 3 
точки зору минулого, теперішнього та майбутнього. Небажані виходи процесу, які можуть бути покриті доступними технологіями, повинні бути ідентифіковані як такі, що мають доступний потенціал циркулярності у формі доступних ресурсів - потенціал з точки зору минулого. Небажані виходи, які не покриваються доступними технологіями, можуть бути визначені як такі, що мають потенціал циркулярності у формі невикористаних резервів - потенціал з точки зору теперішнього; потенціал циркулярності в формі можливостей - потенціал 3 точки зору майбутнього.

Отже, беручи до уваги різні форми прояву потенціалу циркулярності економічної системи території, можна виділити наступні категорії покриття небажаних виходів:

1) фактичне покриття небажаних виходів - доступний потенціал у формі доступних ресурсів (потенціал з точки зору минулого);

2) технічно можливе покриття небажаних виходів доступний потенціал у вигляді невикористаних резервів (потенціал з точки зору теперішнього);

3) потенційне покриття небажаних виходів - доступний або недоступний потенціал у формі можливостей (потенціал з точки зору майбутнього).

Оцінка технічно можливого рівня покриття небажаних виходів процесів території $€$ корисною для плануванні рівня рециклінгу у наступному періоді на основі оцінки невикористаних резервів. Для пошуку таких резервів доцільним є сканування інших сегментів території для виявлення потенційних входів процесів економічної системи. Оцінка потенційно можливого рівня покриття небажаних виходів процесів території може бути корисною для створення передумов якомога повнішого покриття небажаних виходів певного процесу у майбутньому.

Висновки. В контексті кругової економіки розвиток ресурсних циклів набуває нового значення - збереження поетапно створюваної вартості матеріалу, виробу його частин.
За визначенням ресурсний цикл представляє собою сукупність трансфрормацій та просторових переміщень певної речовини або групи речовин, що відбуваються на всіх етапах його використання людиною. Збереження цінності матеріалу/виробу/частин виробу означає подовження їх життєвого циклу. Ми припускаємо, що збереження цінності матеріалу та виробу в економіці якомога довше відбувається за рахунок розвитку структури ресурсних циклів території 3 точки зору замикання та уповільнення матеріальних петель, усунення можливих небажаних виходів процесів. Раціоналізація структури ресурсних циклів у відповідності до цілей кругової економіки може відбуватися за рахунок реконструкції вже існуючих ресурсних циклів, а також фрормування нових. У цьому контексті другий фрагмент ресурсного циклу «перетворення матеріалу у виріб» має особливий інтерес, оскільки основні процеси замикання та уповільнення петель відбуваються переважно у межах цього сегменту. Щоб виміряти структурі зміни ресурсних циклів території, як результат замикання та уповільнення, пропонується використовувати сегментацію ресурсного циклу як підхід до вимірювання відповідного прогресу.

Оскільки ресурсні цикли географфічно розірвані, тобто $€$ певний набір сегментів, що належить території, саме сегментація дозволяє виміряти рівень покриття небажаних виходів процесів крізь сегменти різних типів ресурсних циклів, різних стадій трансформації речовини. Даний підхід дозволяє охопити всі етапи трансформації речовини, а не тільки фази життєвого циклу виробу, оцінка сегменту «перетворення речовини у матеріал» $€$ не менш значущою, ніж сегмент «перетворення матеріалу у виріб», особливо для країн, що виробляють первинні матеріали. Запропонований підхід дозволяє порівнювати схожі сегменти за типом ресурсних циклів та стадіями.

\section{References:}

1.Губанова Е.Р. Механизм экономико-экологического стимулирования использования вторичных ресурсов, Одесса: «ТЭ», 2009, $280 \mathrm{c}$.

2. Комар И. Рациональное использование природных ресурсов и ресурсные циклы, М.: «Наука», 1975, 211 с.

3.Ayres, R.U. Industrial metabolism: theory and policy, The Greening of Industrial Ecosystems, National Academy Press, Washington, 1994, pp. 23-37.

4.Bakker, C.A., Wang, F., Huisman, J., Den Hollander, M. Products that go round: Exploring product life extension through design // Journal of Cleaner Production. Vol. 69, 2014, pp.10-16.

5.Bailey, R., Bras, B., Allen, J.K. Measuring material cycling in industrial systems // Resources, Conservation and Recycling, Vol. 52, 2008, pp.643-652.

6.Benyus, J. Biomimicry: Innovation Inspired by Nature. New York, USA: William Morrow \& Company, 1997

7.Boulding, K.E., The Economics of the Coming Spaceship Earth. In H. Jarrett (ed.). Environmental Quality in a Growing Economy, Baltimore, MD: Resources for the Future/Johns Hopkins University Press, 1966, pp. 3-14.

8.Braungart, M., McDonough, W., Bollinger, A. Cradle-to-cradle design: creating healthy emissions - a strategy for eco-effective product and system design // Journal of Cleaner Production, Vol. 15, 2007, pp. 1337-1348.

9.Blomsma, F., Brennan, G. The Emergence of Circular Economy A New Framing Around Prolonging Resource Productivity // Journal of Industrial Ecology, Special Issue: Exploring the Circular Economy, Vol. 21, No.3, 2017, pp. 603-614.

10. Bruel, A., Kronenberg, J., Troussier, N., Guillaume, B. Linking Industrial Ecology and Ecological Economics: A Theoretical and Empirical Foundation for the Circular Economy // Journal of Industrial Ecology. Vol. 23, No.1, 2018, pp. $12-21$.

11. Cayzer, S., Griffiths, P., Beghetto V. Design of indicators for measuring product performance in the circular economy // International Journal of Sustainable Engineering, Published online: 26 Jun 2017.

12. Chen, W., Graedel, T.E. Anthropogenic cycles of the elements: A critical review // Environmental Science \& Technology, Vol. 46, No.16, 2012, pp. 8574-8586.

13. Commoner, B. The Closing Circle: Nature, Man and Technology. New York, 1971

14. Den Hollander, M.C., Bakker, C.A., Hultink, E.J. Product Design in a Circular Economy: Development of a Typology of 